\title{
ZACHOWANIA ZDROWOTNE I POCZUCIE WŁASNEJ SKUTECZNOŚCI STUDENTÓW POCHODZĄCYCH Z KANADY
}

\author{
HEALTH BEHAVIORS AND SELF-EFFICACY OF STUDENTS FROM THE CANADA \\ Joanna Irena Zalewska-Puchała, Wioleta Gąska, Anna Majda \\ Pracownia Teorii i Podstaw Pielęgniarstwa, Instytut Pielęgniarstwa i Położnictwa, Wydział Nauk o Zdrowiu, Uniwersytet Jagielloński Collegium Medicum \\ DOI: https://doi.org/10.20883/ppnoz.2019.63
}

\section{STRESZCZENIE}

Wstęp. Do Polski coraz częściej przybywają osoby odmiennych kultur, wybierając nasz kraj na miejsce do życia lub tylko nauki. Młodzi Kanadyjczycy wybierają Polskę jako kraj uzyskiwania wyższego wykształcenia. Przywożą ze sobą swoją wielokulturowość, zwyczaje, tradycje i styl życia. Z punktu widzenia szeroko pojętej ochrony zdrowia bardzo ważne jest poznanie ich kultury i zwyczajów, które mogą mieć wpływ na zachowania zdrowotne, a także podejście do zdrowia, choroby oraz leczenia.

Cel pracy. Celem badań było poznanie zachowań zdrowotnych, a także poczucia własnej skuteczności studentów pochodzących z Kanady, studiujących w Polsce. Materiał i metody. Badania przeprowadzono metodą sondażu diagnostycznego, wykorzystano narzędzia badawcze w postaci: autorskiego kwestionariusza ankiety oraz Skali Uogólnionej Własnej Skuteczności autorstwa R. Schwarzera i M. Jerusalem. Analizę statystyczną wykonano przy użyciu pakietu Statistica 10.0, z wykorzystaniem testu niezależności chi-kwadrat Pearsona. W badaniu wzięło udział 62 studentów z Kanady studiujących w Krakowie, Wrocławiu i Warszawie.

Wyniki. Większość badanych studentów prezentowała zachowania prozdrowotne w postaci: regularnego spożywania posiłków o tych samych porach, przesypiania odpowiedniej liczby godzin w ciągu doby. Zachowaniami antyzdrowotnymi dotyczącymi większości studentów były: spożywanie alkoholu, palenie tytoniu, picie kawy, podjadanie między posiłkami. W codziennej diecie ponad połowy badanych studentów dominowały tłuszcze zwierzęce, owoce i pieczywo jasne. Badanych studentów w większości cechował wysoki poziom uogólnionej własnej skuteczności.

Wnioski. Zachowania antyzdrowotne w badanej grupie studentów z Kanady skłaniają do podjęcia działań profilaktycznych, w tym także w zakresie wsparcia akulturacyjnego.

Słowa kluczowe: zachowania zdrowotne, poczucie własnej skuteczności, Kanadyjczycy.

\section{ABSTRACT}

Introduction. People of different cultures are increasingly coming to Poland, choosing our country as a place to live or just study. Young Canadians choose Poland as a country of higher education, presenting their multiculturalism, customs, traditions and lifestyle. From the standpoint of broadly understood health care, it is very important to know their culture and habits that can influence health behaviors, as well as the approach to health, disease and treatment.

Aim of the study. The aim of the study was to learn about health behaviors as well as the sense of self-efficacy of students from the Canadian studying in Poland. Material and methods. The study was conducted by the diagnostic survey method, using the research tools in the form of the author's questionnaire survey and the Scale of Generalized Efficacy by R. Schwarzer and M. Jerusalem. Statistical analysis was performed using Statistica 10.0, using the Pearson chisquare independence test. In the survey was participated 62 students from Canada who live in Krakow, Wrocław and Warszawa.

Results. Most of the students studied presented healthy behaviors in the form of: regular meals at the same times, number of hours over the course of the day. The most prevalent unhealthy behaviors for the majority of students were alcohol consumption, smoking tobacco, coffee drinking, and intercourse between meals. Animal fat, fruit and light bread dominated in the daily diet of over half of the students surveyed. The majority of students studied were characterized by high levels of generalized self-efficacy.

Conclusion. Risky behaviors in the study group of students from Canada tend to undertake broader preventive actions, including acculturation support.

Keywords: health behaviour, self-efficacy, Canadians.

\section{Wstęp}

W drugiej połowie XX w. zachowania zdrowotne nabrały nowego znaczenia, zaczęto poświęcać im więcej uwagi, stały się wskaźnikiem monitorowania zdrowia ludności. Zachowania zdrowotne wynikają z postaw, działań, nawyków, zwyczajów i wartości, które są uznawane przez dane społeczeństwo i mają związek ze sferą zdrowia. Są to między innymi: racjonalne odżywianie się, regularna aktywność fizyczna, unikanie używek, odpowiednia ilość i jakość snu oraz umiejętność radzenia sobie w sytuacjach trudnych, stresowych. Zachowania zdrowotne określane są najczęściej przez wyznaczniki kulturowe i społeczne, które konstruują i ograniczają wybór jednostki [1-4].

W Polsce studiuje wielu młodych Kanadyjczyków. Z raportu "Studenci zagraniczni w Polsce 2017" [5] wynika, 
że w roku akademickim 2016/17 studiowało na naszych uczelniach 65793 studentów zagranicznych ze 166 państw, w tym 384 z Kanady. Najwięcej studentów zagranicznych kształci się w Warszawie, Lublinie i Krakowie. Jak donosi raport [5], liczba studentów zagranicznych ma tendencję wzrostową. Zdaniem autorek artykułu, istnieje konieczność poznania ich mentalności, zwyczajów, stylu życia i zachowań zdrowotnych, ze szczególnym wskazaniem na zachowania ryzykowne. Pozwoli to przewidywać, z jakimi problemami zdrowotnymi mogą się oni borykać [6]

Kanada jest drugim co do wielkości, a jednocześnie jednym z najbardziej wielokulturowych, państwem świata [7]. W Kanadzie mieszkają 34 grupy etniczne liczące po co najmniej 100 tys. osób. Największa grupa etniczna to Anglicy, a następnie Francuzi, Szkoci, Irlandczycy, Niemcy, Włosi, Chińczycy, Ukraińcy oraz rdzenni mieszkańcy Kanady. W państwie mieszkają trzy grupy ludności tubylczej - Indianie, Inuici oraz Metysi [8]. W Kanadzie obowiązują dwa języki oficjalne: angielski (forma pośrednia między brytyjską a amerykańską angielszczyzną) i francuski [9]. Znaczne jest również zróżnicowanie religijne wśród Kanadyjczyków. Według spisu ludności [10] w 2011 r. 67,3\% Kanadyjczyków było chrześcijanami (najczęściej katolikami, a następnie protestantami, prawosławnymi, zielonoświątkowcami). Pozostali wierzący to $w$ kolejności muzułmanie, żydzi, hindusi, baptyści i buddyści. Brak przynależności religijnej zadeklarowało 23,9\% Kanadyjczyków. Kanadyjski system ochrony zdrowia, określany mianem „społeczne ubezpieczenie zdrowotne", finansowany jest z federalnego budżetu państwa, a za jego zarządzanie odpowiedzialne są prowincje. Nieliczne świadczenia specjalistyczne, których wykonanie nie jest objęte gwarancjami publicznymi, mogą być przedmiotem ubezpieczeń prywatnych [11]. Średnia długość życia całej populacji Kanady to 82,2 lata (mężczyźni-80,2; kobiety - 84,1 lata) [12].

\section{Cel}

Celem badań było poznanie zachowań zdrowotnych oraz poczucia własnej skuteczności studentów pochodzących z Kanady studiujących w Polsce.

\section{Materiał i metody}

Badania przeprowadzono metodą sondażu diagnostycznego, z wykorzystaniem narzędzi badawczych w postaci kwestionariusza ankiety własnej konstrukcji i Skali Uogólnionej Własnej Skuteczności (GSES - Generalized Self-Efficacy Scale) autorstwa R. Schwarzera i M. Jerusalem [13]. Kwestionariusz ankiety zawierał 30 pytań zamkniętych dotyczących zachowań zdrowotnych oraz jedno w formie tabeli, uwzględniającej częstotliwość spożywa- nia wybranych produktów żywieniowych. GSES zawierała 10 twierdzeń, skonstruowanych w formie samooceny, na temat radzenia sobie w życiu, wiedzy o własnych możliwościach. Badany określał autentyczność podanych zdań w skali od 1 do 4 (1 oznaczało nie, 2 - raczej nie, 3 - raczej tak, 4 - tak). Zsumowane punkty dawały ogólny wskaźnik samoskuteczności, dzieląc badanych na trzy kategorie: 10-24 pkt (1-4 sten) - osoby z niskim poczuciem samoskuteczności; 25-29 pkt (5-6 sten) - pośrednim; 30-40 pkt (7-10 sten) - wysokim. Każdej badanej osobie obliczono wskaźnik masy ciała (Body Mass Index - BMI) na podstawie deklarowanych cech - wysokości i masy ciała, a następnie dokonano kategoryzacji wyników zgodnie z normami WHO ( $\downarrow 18,5$ - niedowaga; 18,5-24,9 - prawidłowa masa ciała; 25-29,9 - nadwaga; 30 i $\uparrow$ - otyłość) [14]. Analizę statystyczną przeprowadzono w pakiecie Statistica 10.0. Do oceny zależności między zmiennymi zastosowano test chi-kwadrat Pearsona. Przyjęto poziom istotności $\alpha=0,05$.

Badania przeprowadzono, zgodnie z wymogami Deklaracji Helsińskiej, wśród studentów pochodzących z Kanady, studiujących w Polsce, w Krakowie, Wrocławiu, Warszawie. Badani studiowali na kierunkach: medycyna, stomatologia, budownictwo, ekonomia, stosunki międzynarodowe, zarządzanie. Ankiety rozprowadzono wśród 70 respondentów, z czego do analiz wykorzystano 62 w całości wypełnione (16,1\% wszystkich studiujących w czasie badania Kanadyjczyków w Polsce). Wiek badanych zawierał się w przedziale 21-26 lat (śr. 23 lata). Zdecydowana większość respondentów mieszkała $w$ akademikach (77,4\%), pozostali w wynajmowanych mieszkaniach/pokojach. Wśród respondentów prawidłową masę ciała miało $25,8 \%$ badanych, nadwagę $46,8 \%$, a otyłość $27,4 \%$ ankietowanych.

\section{Wyniki}

\section{Zachowania prozdrowotne}

Do zachowań prozdrowotnych poddanych analizie zaliczono: aktywność fizyczną, czas przeznaczony na sen, jakość i czas spożywanych posiłków oraz wypijanych płynów, systematyczną kontrolę masy ciała, systematyczne lekarskie badania okresowe.

Najwięcej spośród badanych studentów (43,5\%) swój czas wolny spędzało pół na pół, aktywnie i biernie (kobiety 35,5\%; mężczyźni 51,6\%). Biernie czas wolny spędzało $32,3 \%$ (K 38,7\%; M 25,8\%), a aktywnie $24,2 \%$ respondentów (K 25,8\%; M 22,6\%).

Codzienną aktywność fizyczną rozumianą jako uprawianie wyczynowo bądź rekreacyjnie sportu zadeklarowało 3,2\% spośród wszystkich respondentów (jedynie kobiety). Aktywność fizyczną 5 razy $w$ tygodniu zade- 
klarowało 17,7\% badanych (K 16,0\%; M 19,4\%), 3-4 razy w tygodniu 27,4\% (K 22,6\%; M 32,3\%), 1-2 razy 33,9\% (K 35,5\%; M 32,3\%). Natomiast nieuprawiających żadnych form aktywności sportowej w czasie wolnym było $17,7 \%$ badanych (K 19,4\%; M 16,0\%)

Większość badanych $(62,9 \%)$ zadeklarowała, że odżywia się regularnie, o stałych porach (niezależnie od ich ilości) (K 61,3\%; M 64,5\%). Regularne spożywanie 5 posiłków dziennie zadeklarowało 17,7\% osób (K 19,4\%; M 16,1\%), 4 positków 24,2\% (K 22,6\%; M 25,8\%), 3 posiłków 16,2\% (K 12,9\%; M 19,4\%), 2 positków 4,8\% badanych (K 6,4\%; M 3,2\%). Pozostałe osoby odżywiały się nieregularnie o różnych porach i różnej ilości spożywanych posiłków. Ostatni posiłek najczęściej (39,7\%) spożywany był przez ankietowanych między godziną 21.00 a 22.00 (K 45,2\%; M 45,2\%). Przed godziną 19.00 ostatni posiłek spożywało 12,1\% respondentów (K 12,9\%; M 3,2\%), 37,9\% około godziny 20.00 ( $\mathrm{K} 29,0 \% ; \mathrm{M} 25,8 \%$ ), zaś 10,3\% po godzinie 22.00 ( $K$ 12,9\%; M 25,8\%).

Analiza preferencji żywieniowych wykazała, iż badani najczęściej spożywali (Tabela 1):

- codziennie: tłuszcze zwierzęce 59,7\%, owoce $54,8 \%$, pieczywo jasne $48,4 \%$;

- często: przetwory mleczne $56,5 \%$, mięso $53,2 \%$, jaja $48,4 \%$, sery $48,4 \%$;

314 - rzadko: rośliny strączkowe $61,3 \%$, ryby $50,0 \%$, tłuszcz roślinny $46,8 \%$, pieczywo ciemne $46,8 \%$, warzywa 43,5\%;

- sporadycznie: ryż $53,2 \%$.

Tabela 1. Częstotliwość spożywania wybranych produktów w badanej grupie

\begin{tabular}{|c|c|c|c|c|}
\hline $\begin{array}{l}\text { Spożycie } \\
\text { produktu }\end{array}$ & $\begin{array}{c}\text { Codziennie } \\
\%\end{array}$ & $\begin{array}{c}\text { Często } \\
\%\end{array}$ & $\begin{array}{c}\text { Rzadko } \\
\%\end{array}$ & $\begin{array}{c}\text { Sporadycznie } \\
\%\end{array}$ \\
\hline Pieczywo ciemne & 11,3 & 22,6 & 46,8 & 19,4 \\
\hline Pieczywo jasne & 48,4 & 24,2 & 11,3 & 16,1 \\
\hline Ryż & 0,0 & 9,7 & 37,1 & 53,2 \\
\hline Mięso & 19,4 & 53,2 & 12,9 & 11,3 \\
\hline $\begin{array}{l}\text { Mleko, przetwory } \\
\text { mleczne }\end{array}$ & 32,3 & 56,5 & 8,1 & 3,2 \\
\hline Ryby & 0,0 & 21,0 & 50,0 & 29,0 \\
\hline Jaja & 27,4 & 48,4 & 14,5 & 9,7 \\
\hline Sery & 29,0 & 48,4 & 16,1 & 6,5 \\
\hline $\begin{array}{c}\text { Rośliny strączkowe } \\
\text { (groch, fasola) }\end{array}$ & 0,0 & 14,5 & 61,3 & 24,2 \\
\hline Tłuszcz zwierzęcy & 59,7 & 9,7 & 11,3 & 19,4 \\
\hline Tłuszcz roślinny & 16,1 & 19,4 & 46,8 & 17,7 \\
\hline Warzywa & 9,7 & 27,4 & 43,5 & 19,4 \\
\hline Owoce & 54,8 & 30,6 & 9,7 & 4,8 \\
\hline
\end{tabular}

Swoją dietę uzupełniało o witaminy, preparaty wzmacniające i mikroelementy 29,3\% ankietowanych ( $\mathrm{K} 41,9 \%$; M 32,3\%). Zadeklarowana ilość wody wypijanej w ciągu dnia to w równych częściach 1-2 litry i mniej niż 1 litr (po $38,7 \%$ ) na dobę, natomiast 22,6\% badanych w ogóle nie piło wody.

Regularnie kontrolowało swoją masę ciała 20,9\% (K 25,8\%; M 16,1\%) badanych studentów. Niestety, w ogóle nie kontrolowało swojej masy ciała 37,1\% (K 29,0\%; M 45,2\%) ankietowanych, a pozostali kontrolę przeprowadzali sporadycznie. Przynajmniej jednorazowo, próbę odchudzania podejmowało $43,1 \%$ respondentów (K 51,6\%; M 45,2\%). W czasie trwania badania na diecie znajdowało się $24,1 \%$ ankietowanych (K 29,0\%; M 22,6\%).

Najczęściej badani studenci przeznaczali na sen okoto 7-6 godzin w ciągu doby $(55,2 \%$; K 61,3\% i M 61,3\%), a następnie 5 godzin i mniej 24,1\% (K 16,1\%; M 16,1\%) i 9-8 godzin 19,0\% (K 16,1\%; M 22,6\%). Powyżej 9 godzin w ciągu doby spało 1,7\% ankietowanych (tykko kobiety 6,5\%).

Lekarskim badaniom kontrolnym poddawało się regularnie zaledwie $8,6 \%$ badanych studentów (K 25,8\%; M 12,9\%)

\section{Zachowanie antyzdrowotne (ryzykowne)}

Do zachowań antyzdrowotnych poddanych analizie w prezentowanych badaniach zaliczono: picie alkoholu, palenie tytoniu, używanie narkotyków i sterydów, „przygodne" stosunki seksualne, spożywanie produktów typu fast food, podjadanie między positkami, dosalanie gotowych potraw, spożywanie kawy.

Badania pokazały, iż przeważająca większość badanych studentów (87,1\%) spożywała alkohol (K 90,3\%; M 83,9\%). Alkohole wysokoprocentowe spożywato $79,0 \%$ badanych (K $74,2 \%$; $M$ 83,9\%), wino $64,5 \%$ ( $\mathrm{K} 74,2 \% ; \mathrm{M} 54,8 \%$ ), a piwo 80,7\% (K 77,4\%; M 83,9\%). W ciągu miesiąca badani najwięcej spożywali piwa (K 4,63 I; M 4,5I), a następnie wina (K 2,26 I; M 3,41 I) i alkoholu wysokoprocentowego (K 2,24 I; M 3,04 I). Badani najczęściej przestawali pić alkohol w czasie imprez wtedy, gdy czuli się pijani (31,1\%; K 35,7\% i M 26,9\%), a następnie w kolejności: gdy kończył się alkohol lub fundusze (24,5\%; K 14,3\% i M 34,6\%), kiedy czuli się lekko pijani (19,7\%; tylko kobiety $39,3 \%)$, kiedy "urywał się film" (13,2\%; K 7,1\% i M 19,2\%), kiedy robiło się im niedobrze (11,4\%; K 3,6\% i M 19,2\%).

W czasie badania połowa ankietowanych zadeklarowała, iż nałogowo pali tytoń (50,0\%; K 54,8\% i M 45,2\%). W przeszłości paliło 17,7\% badanych (K 22,6\%; M 12,9\%). Nieskuteczne próby rzucenia palenia przynajmniej raz podejmowało w przeszłości 24,3\% (K 20,8\%; M 27,8\%), 2-3 
razy 29,2\% (K 41,7\%; M 16,7\%) i 4-5 razy 12,5\% (K 8,3\%; M 16,7\%). Najwięcej spośród osób palących (31,9\%) paliło od około 2 lat (K 25,0\%; M 38,9\%), a następnie $26,4 \%$ co najmniej 3 lat (K 25,0\%; M 27,8\%), 19,4\% przez rok ( $\mathrm{K}$ 16,7\%; M 22,2\%), 20,2\% kilka miesięcy ( $\mathrm{K}$ 29,1\%; $\mathrm{M} 11,2 \%$ ), a przez kilka tygodni 2,1\% badanych (tylko kobiety 4,2\%). Deklarowana liczba papierosów wypalanych dziennie to najczęściej od 10 do 15 (42,4\%; K 29,2\% i M 55,6\%), a następnie 4-9 (41,6\%; K 50,0\% i M 33,3\%), 1-3 (11,2\%; K 16,7\% i M 5,6\%) i 16-20 (4,9\%; K 4,2\% i M 5,6\%).

Do zażywania narkotyków przyznało się 11,3\% (K 6,5\%; M 16,1\%) badanych. Do odbywania "przygodnych" stosunków seksualnych (z przypadkową, nowopoznaną osobą) przyznało się $45,2 \%$ badanych studentów (K $64,5 \%$; M 71,0\%), natomiast środki antykoncepcyjne w postaci prezerwatyw stosowało 59,7\% ankietowanych (K 29,0\%; M 90,3\%)

Badania wykazały, iz badani często (5-4 razy w tygodniu) odżywiali się spożywając produkty typu fast food, zachowanie takie dotyczyło niemal połowy ankietowanych (41,9\%; K 38,7\% i M 45,2\%). Większość studentów podjadała między posiłkami (61,3\%; K 64,5\%; M 58,1\%). Produktami, jakie badani podjadali między posiłkami, najczęściej były słodycze (55,3\%; K 60,0\% i M 50,0\%), a następnie słone przekąski typu chipsy, krakersy itp. (34,2\%; K 30,0\% i M 38,9\%) i owoce, warzywa (10,5\%; K 10,0\% i M 11,1\%). Wśród badanych osób 43,5\% dosalało gotowe potrawy (K 51,6\%; M 35,5\%).

Przeważająca większość badanych studentów (85,5\%) zadeklarowała, iż pije kawę codziennie, najczęściej w ilości 2 filiżanek dziennie (49,2\%; K 46,4\% i M 52,0\%), a następnie 3 filiżanek (26,1\%; K 32,1\% i M 20,0\%), 1 filiżanki (21,1\%; K 14,3\% i M 28,0\%) i 4 filiżanek (3,8\%; tylko kobiety $7,1 \%)$.

\section{Sposoby radzenia sobie ze stresem}

Najczęstszym sposobem radzenia sobie ze stresem było wśród badanych palenie papierosów, które wskazało 33,8\% osób (K 38,7\%; M 29,0\%). Często deklarowanym sposobem było także uprawianie sportu (21,0\%; K 22,6\% i M 19,4\%) ispotkania z przyjaciółmi oraz wyjście na spacer (po K 16,1\%; M 16,1\%). Spożywanie alkoholu było metodą odreagowania dla 8,1\% badanych (K 3,2\%; M 12,9\%), zaś przyjmowanie leków uspokajających dla 4,8\% (K 3,2\%; M 6,5\%) ankietowanych.

Autorki podjęły próbę zdiagnozowania zależności pomiędzy wybranymi zmiennymi, a wszystkimi badanymi zachowaniami zdrowotnymi ankietowanych. Istotne zróżnicowanie dotyczyło takich zmiennych, jak:
Miejsce zamieszkania istotnie różnicowało: sposób spędzania czasu wolnego $\left(\chi^{2}=13,95 ; p<0,001\right)$; częstotliwość podejmowania aktywności fizycznej $\left(\chi^{2}=10,37\right.$; $p<0,04)$; regularne odżywianie się $\left(\chi^{2}=17,92 ; p<0,002\right)$; podjadanie pomiędzy positkami $\left(\chi^{2}=4,98 ; p<0,03\right)$; godziny spożywania ostatniego posiłku $\left(\chi^{2}=9,70 ; p<0,03\right)$; uzupełnianie diety 0 witaminy, preparaty wzmacniające oraz mikroelementy $\left(\chi^{2}=13,33 ; p<0,001\right)$; próby odchudzania się $\left(\chi^{2}=3,84 ; p<0,05\right)$; stosowanie diety $\left(\chi^{2}=9,27\right.$; $p<0,003)$; częstotliwość kontrolowania swojej masy ciała $\left(\chi^{2}=9,97 ; p<0,007\right)$; zażywanie sterydów $\left(\chi^{2}=9,66\right.$; $p<0,008)$; regularne kontrolne badania lekarskie $\left(\chi^{2}=6,39\right.$; $p<0,02)$. Osoby mieszkające $w$ wynajmowanych mieszkaniach częściej: czas wolny spędzały aktywnie, poddawały się regularnym lekarskim badaniom kontrolnym, zażywały sterydy na poprawę sylwetki, kontrolowały swoją masę ciała, stosowały dietę, podejmowały próby odchudzania się, suplementowały dietę, uprawiały sport w czasie wolnym. $\mathrm{Na}$ tomiast osoby mieszkające w akademikach częściej: podjadały pomiędzy posiłkami głównymi, odżywiały się nieregularnie, później spożywały ostatni posiłek w ciągu dnia.

BMI istotnie różnicowało: sposób spędzania czasu wolnego $\left(\chi^{2}=27,57 ; p<0,001\right)$; częstotliwość podejmowania aktywności fizycznej $\left(\chi^{2}=28,31 ; p<0,001\right)$; regularne spożywanie posiłków $\left(\chi^{2}=30,17 ; p<0,001\right)$; podjadanie pomiędzy posiłkami $\left(\chi^{2}=8,36 ; p<0,02\right)$; godzinę spożywania ostatniego posiłku $\left(\chi^{2}=26,09 ; p<0,001\right)$; częstość uzupełniania diety 0 witaminy, preparaty wzmacniające oraz mikroelementy $\left(\chi^{2}=6,66 ; p<0,04\right)$; stosowanie diety $\left(\chi^{2}=7,89 p<0,02\right)$; kontrolowanie swojej masy ciała $\left(\chi^{2}=13,99 ; p<0,008\right)$; moment, w jakim kończyły picie alkoholu $\left(\chi^{2}=20,79 ; p<0,008\right)$; zażywanie narkotyków $\left(\chi^{2}=9,04 ; p<0,02\right)$. Osoby z niższym wskaźnikiem BMI częściej: preferowały aktywne formy wypoczynku, w ciągu tygodnia uprawiały sport, stosowały suplementy diety, kontrolowały swoją masę ciała, kończyły picie alkoholu wówczas, kiedy czuły się lekko pijane. Natomiast osoby z wyższym wskaźnikiem BMI częściej: odżywiały się nieregularnie, podjadały pomiędzy posiłkami głównymi, później spożywały ostatni posiłek w ciągu dnia, stosowały dietę, kończyły picie w czasie imprez, gdy zabrakło alkoholu lub funduszy na jego zakup, zażywały narkotyki.

Płeć istotnie różnicowała: moment, w jakim badani kończyli picie alkoholu $\left(\chi^{2}=17,35 ; p<0,002\right)$; zażywanie sterydów na poprawę sylwetki $\left(\chi^{2}=9,19 ; p<0,02\right)$; stosowanie antykoncepcji w postaci prezerwatyw $\left(\chi^{2}=24,78\right.$; $p<0,001)$. Kobiety częściej kończyły picie alkoholu wówczas, kiedy czuły się lekko pijane, zaś mężczyźni, gdy zabrakło alkoholu lub funduszy na jego zakup. Mężczyźni częściej zażywali sterydy oraz stosowali prezerwatywy. 
Wiek nie różnicował istotnie żadnego z badanych zachowań zdrowotnych.

\section{Analiza wyników Skali Poczucia Własnej Skuteczności}

Uzyskane przez badanych wyniki w Skali Uogólnionej Własnej Skuteczności (GSES) mieściły się w przedziale 2-10 stena, śr. 6,95 stena (SD 1,55; Me 7). Najwięcej uzyskanych wyników mieściło się w obrębie od 7 do 8 stena (łącznie $58,1 \%)$. Interpretacja wyników w skali stenowej pozwoliła podzielić badanych na trzy grupy. Największą grupę $(69,3 \%)$ stanowiły osoby z wysokim poziomem uogólnionej własnej skuteczności, poziom średni reprezentowany był przez niemal $1 / 4$ badanych $(24,2 \%)$, natomiast niski przez $6,5 \%$ respondentów. Warto zaznaczyć, że niski poziom samoskuteczności dotyczył jedynie kobiet.

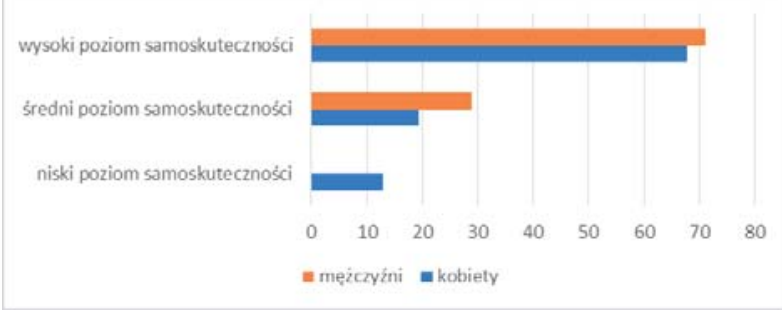

Rycina 1. Poziom poczucia własnej skuteczności badanych studentów

Szczegółowa analiza odpowiedzi na pytania GSES wykazała, że większość respondentów raczej jest w stanie: znaleźć kilka rozwiązań, jeśli zmagają się z jakimś problemem (79\%); rozwiązać trudne sytuacje, jeśli tylko wystarczająco się postarają (67,7\%); poradzić sobie w sytuacjach zaskakujących i nieoczekiwanych dzięki swojej pomysłowości $(67,7 \%)$; poradzić sobie niezależnie od tego, co ich spotyka (66,1\%). Ponad połowa badanych zadeklarowała, że raczej: wie co robić, jeśli znajdzie się w kłopotliwej sytuacji (62,9\%); jest w stanie rozwiązać większość problemów, jeśli włoży w to odpowiednio dużo wysiłku (61,3\%); potrafi zachować spokój w obliczu trudności, gdyż może polegać na swoich umiejętnościach radzenia sobie (59,7\%); jest przekonana, że skutecznie poradziłaby sobie z niespodziewanymi sytuacjami (54,9\%); zna sposoby, aby osiągnąć to, czego chce, nawet jeśli ktoś im się sprzeciwia $(51,6 \%)$. Połowa ankietowanych potrafi łatwo trzymać się swoich celów i je osiągać.

Badanie korelacji pomiędzy wynikami uzyskanymi w GSES, a wybranymi zachowaniami zdrowotnymi, prezentowanymi przez badanych, wykazało, że poziom poczucia własnej skuteczności różnicował istotnie jedynie, spożywanie alkoholu $\left(\chi^{2}=4,38 ; p<0,04\right)$ i odbywanie "przygodnych" stosunków seksualnych $\left(\chi^{2}=5,20 ; p<\right.$ $0,03)$. Osoby mające wysoki poziom poczucia własnej skuteczności częściej: deklarowały picie alkoholu, ryzykowne zachowania seksualne.

Nie wykazano istotnej zależności pomiędzy poczuciem samoskuteczności badanych a: paleniem tytoniu $\left(\chi^{2}=2,94\right.$; $p=0,229)$; stosowaniem środków antykoncepcyjnych w postaci prezerwatyw $\left(\chi^{2}=0,04 ; p=0,976\right)$; zażywaniem narkotyków i sterydów $\left(\chi^{2}=0,95 ; p=0,618\right) ; B M I$ $\left(\chi^{2}=1,30 ; p=0,520\right)$; sposobem spędzania wolnego czasu $\left(\chi^{2}=5,81 ; p=0,054\right)$; podjadaniem pomiędzy positkami $\left(\chi^{2}=0,04 ; p=0,840\right)$; dosalaniem gotowych potraw $\left(\chi^{2}=0,02 ; p=0,878\right)$.

\section{Dyskusja}

Zdaniem autorek artykułu zachowania zdrowotne młodzieży mogą zmieniać się znacząco z chwilą samodzielnego zamieszkania, tym bardziej zmieniać się one mogą, jeśli opuszczenie domu rodzinnego tączy się ze zmianą kraju zamieszkania. W prezentowanych badaniach zachowania zdrowotne Kanadyjczyków studiujących w Polsce znacząco różnią się od deklarowanych przez młodzież w kraju ich pochodzenia.

Uzyskane w toku badań wyniki dotyczące ryzykownych zachowań zdrowotnych studentów postanowiono porównać z wynikami pochodzącymi z raportu społeczno-ekonomicznej bazy danych statystycznych Kanady - CANSIM [15], dotyczących osób w wieku 20-34 lata. Dane CANSIM [16] pokazują, że spada liczba osób deklarujących się jako nałogowi palacze: $w 2010$ r. było ich 27,1\% (M 24,2\%; K 17,4\%), a w 2014 r. 24,6\% (M 29,6\%; K 19,4\%). W prezentowanych badaniach aż połowa respondentów zadeklarowała, iż pali papierosy, przy czym to kobiety były częściej nałogowymi palaczkami. Również picie alkoholu zadeklarowało zdecydowanie więcej badanych niż zadeklarowal ich rówieśnicy w Kanadzie. W niniejszych badaniach niemal 90\% ankietowanych studentów zadeklarowało spożywanie alkoholu (częściej kobiety), przy czym niemal $80 \%$ alkohole wysokoprocentowe (częściej mężczyźni). W Kanadzie odsetek osób pijących w wieku od 20 do 34 lat według raportu CANSIM [16] wynosi 30,5\% (M 37,1\%; K 23,7\%). Najczęściej spożywanym alkoholem wśród badanych było piwo. Według danych z 2015 r. dotyczących sprzedaży alkoholu na terenie Kanady najpopularniejszym spożywanym alkoholem przez Kanadyjczyków również jest piwo [17] Do zażywania narkotyków przyznało się w niniejszych badaniach 11,3\% studentów, natomiast raport OSDUHS [18] z 2017 r. donosi, iż marihuanę zażywało 19\% studentów w Ontario. Środki antykoncepcyjne w postaci prezerwatyw stosowała ponad połowa ankietowanych. Uzyskane 
dane są zbieżne z wynikami uzyskanymi przez Boyce i wsp. [19] oraz Milhausen i wsp. [20], w których niemal połowa badanych studentów w Kanadzie zadeklarowała stosowanie prezerwatyw. Jednakże wyników Milhausen i wsp. nie można porównywać wprost, ponieważ w niniejszych badaniach pytano o stosowanie prezerwatyw: zazwyczaj, a $w$ badaniach Milhausen i wsp.: podczas ostatniego stosunku. Analiza preferencji żywieniowych wykazała, iż ponad połowa badanych spożywała codziennie owoce $(54,8 \%)$, podczas gdy w raporcie CANSIM codzienne spożywanie warzyw i owoców zadeklarowało 38,8\% Kanadyjczyków [16]. Prezentowane badania wykazały, iż badani często odżywiali się, spożywając produkty typu fast food. Zachowanie takie dotyczyło niemal połowy ankietowanych. Jak się wydaje, może to być efektem przyzwyczajeń wyniesionych z szkoły średniej, ponieważ uzyskane wyniki pokrywają się z badaniami Velazquez i wsp. [21], które wskazują na częste codzienne spożycie produktów fast food wśród uczniów szkół średnich, a także Lillico i wsp. [22], które pokazują, iż uczniowie prócz samodzielnego spożywania fast food przynajmniej raz w tygodniu (70\%) spożywają posiłki z rodziną $w$ restauracjach fast food. Tylko niemal $1 / 4$ badanych studentów (K 25,8\%; M 22,6\%) zadeklarowała, iż czas wolny spędza aktywnie, podczas gdy w Kanadzie ponad połowa osób w wieku 20-34 lata (K 51,9\%; M 61\%) zadeklarowała aktywność fizyczną w czasie wolnym [16].

Według raportu CANSIM [16] 42\% osób w wieku 20-34 lata miało nadwagę lub otyłość, natomiast w niniejszych badaniach nadwagę na podstawie BMI zdiagnozowano u 46,8\%, a otyłość 27,4\% studentów.

\section{Wnioski}

1. Większości badanych studentów dotyczyły takie zachowania prozdrowotne, jak regularne spożywanie posiłków o tych samych porach, liczba godzin przesypianych w ciągu doby.

2. Zachowaniami antyzdrowotnymi prezentowanymi przez większość badanych studentów było: spożywanie alkoholu, palenie tytoniu, picie kawy, podjadanie między posiłkami.

3. W codziennej diecie ponad połowy badanych studentów dominowały tłuszcze zwierzęce, owoce i pieczywo jasne, często spożywali mięso, przetwory mleczne, jaja, sery, fast food, rzadko - rośliny strączkowe, ryby, warzywa, ciemne pieczywo, a sporadycznie - ryż.

4. Większość badanych studentów charakteryzowała nadwaga i otyłość.
5. Badanych studentów w większości cechował wysoki poziom uogólnionej własnej skuteczności. Studenci ci istotnie częściej deklarowali picie alkoholu, ryzykowne zachowania seksualne.

\section{Oświadczenia}

Oświadczenie dotyczące konfliktu interesów

Autorzy deklarują brak konfliktu interesów.

Źródła finansowania

Autorzy deklarują brak źródeł finansowania.

\section{Piśmiennictwo}

1. Posłuszna M. Zachowania prozdrowotne i ryzykowne dla zdrowia w społeczeństwie polskim. Pielęgniarstwo Polskie. 2011; 40 (2): 91-94.

2. Binkowska-Bury M, Marć M, Januszewicz P. Wiedza o zdrowiu a zachowania ryzykowne w środowisku młodzieży akademickiej. Medycyna Ogólna. 2010; 16: 100-113.

3. Głowacka MD, Zdanowska J. Wymiary zdrowia. W: Zdrowie publiczne w Polsce. red. Głowacka MD, Wolters Kluwer Polska SA, Warszawa 2013, s. 17-21.

4. Heszen I, Sęk H. Behawioralne uwarunkowania zdrowia i choroby. W: Psychologia zdrowia, red. Heszen I, Sęk H, Wydawnictwo Naukowe PWN, Warszawa 2007, s. 91-105

5. Studenci zagraniczni w Polsce 2017. http://www.studyinpoland.pl/konsorcjum- 2016.pdf [data dostępu: 10.01.2018].

6. Zalewska-Puchała J, Majda A, Śmiałek D. Zachowania zdrowotne studentów pochodzących z Tajwanu studiujących w Polsce. Problemy Pielęgniarstwa. 2013: 21(3); 374-381.

7. Kanada. https://encyklopedia.pwn.pl [data dostępu: 10.01.2018]

8. Statistics Canada, Quarterly Demographic Estimates. http:// www.statcan.gc.ca-eng.pdf [data dostępu: 10.01.2018].

9. Statistics Canada: Population by knowledge of official language, by province and territory. http://www12.statcan.gc.ca [data dostępu: 10.01.2018]

10. 2011 National Household Survey: Immigration, place of birth, citizenship, ethnic origin, visible minorities, language and religion http://www.statcan.gc.ca [data dostępu: 10.01.2018]

11. Canada's Health Care System. https://www.canada.ca [data dostępu: 08.03.2018].

12. Word Health Rankings http://www.worldlifeexpectancy.com [data dostępu: 08.03.2018].

13. Generalized Self-Efficacy Scale. http://userpage.fu-berlin de/ health/polish.htm [data dostępu: 10.04.2017].

14. BMI classification. http://apps.who.int/bmi/index [data dostępu: 12.04.2016].

15. Statisics Canada, CANSIM http://www5.statcan.gc.ca [data dostępu: 08.03.2018].

16. Statistics Canada, CANSIM, tabela 105-0501 i nr katalogowy. 82-221-X [data dostępu: 08.03.2018].

17. Rynek produktów alkoholowych w Kanadzie. Wydział Promocji Handlu i Inwestycji Konsulatu Generalnego RP w Montrealu. https://canada.trade.gov.pl-pdf [data dostępu: 12.04.2017].

18. Boak A, Hamilton EM, Adlaf EM, Mann RE. Drugs Use Among Ontario Students 1977-2017. Detailed OSDUHS findings (CAMH Research Document Series No. 46) Centre for Addiction and Mental Health, Toronto 2017.

19. Boyce W, Doherty-Poirier M, MacKinnon D, Fortin Ch, Saab H, King M, Gallupe O. Sexual Health of Canadian young: Find ings from the Canadian Youth, Sexual Health and HIV/AIDS Study. The Canadian Journal of Human Sexuality, 2006, Vol 15(2): 58-69. 
20. Milhausen RR, McKay A, Graham CA, Crosby RA, Yarber WL, Sanders SA. Prevalence and predictors of condom use in a national sample of Canadian university students. The Canadian Journal of Human Sexuality, December 2013, Vol. 22(3): 142-151.

21. Velazquez CE, Black JL, Billette JM, Ahmadi N, Chapman GE. A Comparison of Dietary Practices at or En Route to School between Elementary and Secondary School Students in Vancouver, Canada. Journal of the Academy of Nutrition and Dietetics 2015 Aug;115(8):1308-17. doi: 10.1016/j.jand.2015.02.030.

22. Lillico HG, Hammond D, Manske S, Murnaghan D. The prevalence of eating behaviors among Canadian youth using crosssectional school-based surveys. BMC Public Health. $2014 \mathrm{Apr}$ 7(14):323. doi: 10.1186/1471-2458-14-323.
Zaakceptowano do edycji: 15.12 .2019

Zaakceptowano do publikacji: 15.02.2020

Adres do korespondencji:

Joanna Zalewska-Puchała

Pracownia Teorii i Podstaw Pielęgniarstwa

Instytut Pielęgniarstwa i Położnictwa

Wydział Nauk o Zdrowiu

Uniwersytet Jagielloński Collegium Medicum

ul. Michałowskiego 12

31-126 Kraków

tel. 01263362 59, 508158785 